\title{
The Influence of Tidal Marshes on Upland Groundwater Discharge to Estuaries
}

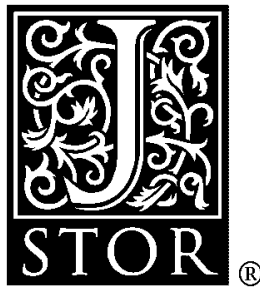

\author{
Judson W. Harvey; William E. Odum \\ Biogeochemistry, Vol. 10, No. 3, Groundwater Inputs to Coastal Waters. (Aug., 1990), pp. \\ 217-236.
}

Stable URL:

http://links.jstor.org/sici?sici=0168-2563\%28199008\%2910\%3A3\%3C217\%3ATIOTMO\%3E2.0.CO\%3B2-4

Biogeochemistry is currently published by Springer.

Your use of the JSTOR archive indicates your acceptance of JSTOR's Terms and Conditions of Use, available at http://www.jstor.org/about/terms.html. JSTOR's Terms and Conditions of Use provides, in part, that unless you have obtained prior permission, you may not download an entire issue of a journal or multiple copies of articles, and you may use content in the JSTOR archive only for your personal, non-commercial use.

Please contact the publisher regarding any further use of this work. Publisher contact information may be obtained at http://www.jstor.org/journals/springer.html.

Each copy of any part of a JSTOR transmission must contain the same copyright notice that appears on the screen or printed page of such transmission.

The JSTOR Archive is a trusted digital repository providing for long-term preservation and access to leading academic journals and scholarly literature from around the world. The Archive is supported by libraries, scholarly societies, publishers, and foundations. It is an initiative of JSTOR, a not-for-profit organization with a mission to help the scholarly community take advantage of advances in technology. For more information regarding JSTOR, please contact support@jstor.org. 


\title{
The influence of tidal marshes on upland groundwater discharge to estuaries
}

\author{
JUDSON W. HARVEY \& WILLIAM E. ODUM \\ Department of Environmental Sciences, Clark Hall, University of Virginia, Charlottesville, VA \\ 22903, USA
}

Key words: groundwater, hydrology, pore water chemistry, salt marshes, solute transport, tidal freshwater marshes

\begin{abstract}
We investigated subsurface hydrology in two fringing tidal marshes and in underlying aquifers in the coastal plain of Virginia. Vertical distributions of hydraulic conductivity, hydraulic head and salinity were measured in each marsh and a nearby subtidal sediment. Discharge of hillslope groundwater into the base of the marshes and subtidal sediment was calculated using Darcy's law. In the marshes, fluxes of pore water across the sediment surface were measured or estimated by water balance methods. The vertical distribution of salt in shoreline sediments was modeled to assess transport and mixing conditions at depth.

Hydraulic gradients were upward beneath shoreline sediments; indicating that groundwater was passing through marsh and subtidal deposits before reaching the estuary. Calculated discharge (6 to 10 liters per meter of shoreline per day) was small relative to fluxes of pore water across the marsh surface at those sites; even where discharge was maximal (at the upland border) it was 10 to 50 times less than infiltration into marsh soils. Pore water turnover in our marshes was therefore dominated by exchange with estuarine surface water. In contrast, new interstitial water entering subtidal sediments appeared to be primarily groundwater, discharged from below.

The presence of fringing tidal marshes delayed transport and increased mixing of groundwater and solute as it traveled towards the estuaries. Soil-contact times of discharged groundwater were up to $100 \%$ longer in marshes than in subtidal shoreline sediments. Measured and modeled salinity profiles indicated that, prior to export to estuaries, the solutes of groundwater, marsh pore water and estuarine surface water were more thoroughly mixed in marsh soils compared to subtidal shoreline sediments. These findings suggest that transport of reactive solutes in groundwater may be strongly influenced by shoreline type. Longer soil-contact times in marshes provide greater opportunity for immobilization of excess nutrients by plants, microbes and by adsorption on sediment. Also, the greater dispersive mixing of groundwater and pore water in marshes should lead to increased availability of labile, dissolved organic carbon at depth which could in turn enhance microbial activity and increase the rate of denitrification in situations where groundwater nitrate is high.
\end{abstract}

\section{Introduction}

Groundwater discharge to estuarine waters has been a topic of theoretical and practical interest for at least a century (reviewed in Freeze \& Cherry 1979). Most work has stressed controls on seawater intrusion to freshwater aquifers (e.g. Henry 1960; Cooper et al. 1964) and it has been only recently that field measurements of groundwater discharge have shown the importance of subsurface flow on water and nutrient budgets in estuaries. For example, upland aquifers 
contribute to direct groundwater discharge greater than $20 \%$ of the freshwater and $75 \%$ of the nitrogen that enters Great South Bay, New York (Bokuniewicz 1980; Capone \& Bautista 1985). Excess nitrogen in groundwater derived from sewage and fertilizer has drastically affected water quality in other estuaries and coastal lagoons as well (Johannes \& Hearn 1985).

In the Mid-Atlantic and Northeast United States, groundwater discharge to estuaries has been shown to be focused at the shoreline in a zone typically extending 30 to $100 \mathrm{~m}$ offshore (Lee 1980; Valiela et al. 1980; Bokuniewicz 1980; Capone \& Bautista 1985). Most studies in estuaries have been conducted on permanently flooded (subtidal) estuarine shorelines; fewer studies have investigated upland groundwater discharge along shorelines where intertidal marshes are present. Intertidal marshes comprise $40 \%$ of the area of coastal lagoon basins in the eastern United States (Hayden \& Dolan 1979). The marshes are often present at upland borders where they have maximal potential to interact with discharging groundwater from hillslope aquifers. Yet the effect of tidal marshes, either on the magnitude of groundwater or upon the fate of dissolved constituents being transported with the groundwater, is poorly understood.

We studied groundwater discharge from upland aquifers into two marshes on the coastal plain of Virginia. Our investigations had a dual purpose: first, to examine controls on the magnitude of fluxes, including stratigraphy and hydraulic properties of marsh soils and underlying aquifers; second to assess the fate of groundwater discharged to the marsh. We began by formulating mass balance equations for pore water and solute for each shoreline type. Next, pore water and solute budgets were developed from field data, and pore water salinities from marshes and subtidal shorelines were compared with profiles generated by a solute transport model. Subsurface fluxes, residence times and the degree of dispersive mixing of groundwater and marsh pore water were estimated and compared between marsh and subtidal situations.

\section{Site description and methods}

The Mid-Atlantic coastal plain from New Jersey to North Carolina is composed of sands and clays of Cretaceous age or younger that were deposited atop bedrock in fluvial, estuarine, or marine environments (Back 1966). Stratigraphic layers become thicker as they slope gently from west to east. Maximum thickness of sediments are 200 to $400 \mathrm{~m}$ at the Atlantic Ocean shoreline. The general movement of groundwater in the coastal plain is from recharge sites in the west to discharge sites in the eastern rivers, estuaries and the Atlantic Ocean. Localized recharge and discharge occurs over the entire coastal plain. Figure 1 is a schematic cross sectional view of two estuarine shorelines, with and without a tidal marsh. Estuarine deposits have a high organic content and are of Holocene age. Mineral materials of these deposits are clays with some reworked sands from the underlying stratigraphic unit occurring at the base of the deposits; marsh deposits are generally less than $5 \mathrm{~m}$ thick (Kraft et al. 1979). Underlying 
(a)

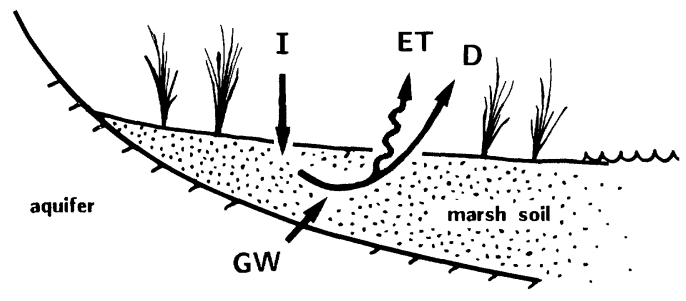

(b)

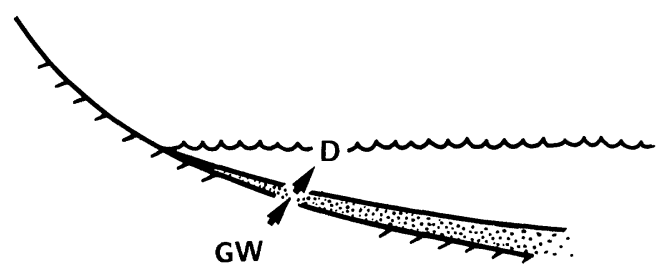

Fig. 1. Subsurface hydrological transport pathways at estuarine shorelines: $(a)$ tidal marsh; $(b)$ subtidal. The subsurface water fluxes are: $I$, infiltration flux; $G W$, groundwater discharge flux; $E T$, evapotranspiration flux; $D$, pore water drainage flux. Note that only $D$ and $G W$ occur if sediment is subtidal, i.e. permanently flooded and unvegetated.

aquifers are of Pleistocene age or older and have very low organic content, containing variable mixtures of sands and clays with some discontinuous layers of nearly pure clay (Winner 1975; Kraft et al. 1979; Back 1966). In Virginia, the water table aquifer is typically 3 to $20 \mathrm{~m}$ thick and is underlain by the semiconfining layers of a clayey-sand aquifer (Pliocene age) that contains fresh interstitial water (Cederstrom 1943).

To quantify subsurface transport in shoreline environments it is useful to distinguish between interstitial water of Holocene or younger deposits and the water of the older, underlying aquifer. Interstitial water in shoreline sediments (marsh soil or subtidal beach sediment) is referred to as pore water in this paper. Interstitial water in the aquifer beneath shoreline sediments is referred to as groundwater. Groundwater discharge is defined as the surface transport of groundwater from the underlying aquifer into the base of the marsh soil or subtidal sediment (Fig. 1). Groundwater from below is the most likely source of new pore water to a subtidal sediment; other possible pathways are by water flow induced by bioturbation and bubble ebulliton. In tidal marsh soils, infiltration of flooding tidal water or precipitation is an additional source of water input (Nuttle and Hemond 1988). Export of pore water from marsh soils occurs by pore water drainage (Harvey et al. 1987) and by evapotranspiration (Dacey \& Howes 1984). 


\section{Pore water balance}

The net result of subsurface fluxes described above, averaged over many tidal cycles, is a steady balance of subsurface inflows and outflows from a marsh soil;

$$
q_{G W}+q_{I}-q_{D}-q_{E T}=0
$$

with inflows by groundwater discharge $\left(q_{G W}\right)$ and infiltration $\left(q_{I}\right)$ treated as positive and outflows by evapotranspiration $\left(q_{E T}\right)$ and drainage $\left(q_{D}\right)$ treated as negative. The specific discharge $(q)$ is defined by:

$$
q=-K \frac{\mathrm{d} h}{\mathrm{~d} z}
$$

where the hydraulic conductivity $(K)$ is a constant which expresses the effect of water (e.g. viscosity) and marsh soil properties (e.g. permeability) on the rate at which water can flow through soil for a given driving force. The driving force is the gradient in hydraulic head $(\mathrm{d} h / \mathrm{d} z)$ where hydraulic head $(h)$ is a measure of the potential energy per unit weight of water at a point in the flow system.

$$
h=\frac{P}{\rho g}+z
$$

Hydraulic head has two components, pressure head and elevation head, expressed respectively as the pore pressure divided by the unit weight of water $(P / \rho g)$ and the elevation of the measurement above an arbitrary datum $(z)$. In marsh systems hydraulic head is measured as the height to which water rises in a piezometer.

The pore water balance of Eq. (1) can be rearranged to find the net flux of water across the sediment surface to the estuary and atmosphere. The difference between surface influxes and effluxes yields a net flux across the surface equal to the groundwater discharge rate.

$$
q_{I}-q_{D}-q_{E T}=-q_{G W} .
$$

Infiltration and evapotranspiration do not occur in subtidal estuarine shorelines. If Eq. (1) is modified to reflect this difference, the net fluxes across sediment surface is also found to equal the groundwater discharge.

$$
-q_{D}=-q_{G W} .
$$

Equations (4) and (5) indicate that net fluxes across the marsh or subtidal sediment surface should equal the groundwater discharge rate, regardless of the magnitude of the other fluxes. Away from creekbanks, the additional fluxes in marsh soils $(I, D$, and $E T)$ do not contribute to a net, vertical advection of 
water. However, these fluxes do contribute to solute mixing by hydrodynamic dispersion.

\section{Salt balance}

Solute transport in soils occurs by the combined effects of advection and dispersion. Solute advection occurs with the bulk motion of the pore water and is described by an average linear velocity $(v)$ which equals the specific discharge $(q)$ divided by the effective porosity of the soil $\left(n_{e}\right)$. Solute dilution is caused by diffusion, which results from random, molecular scale motions, and hydrodynamic dispersion, which is caused by transport in a large number of pores in the soil, each with a slightly different velocity. The coefficient of dispersion, $D_{l}$, is equal to the sum of both components:

$$
D_{l}=D_{s}+v \alpha
$$

where $D_{s}$ is the diffusion in soil of a given porosity and tortuosity, $v$ is the velocity, and $\alpha$ is a length scaling factor associated with the mean length of an independent flow path in the system. Assuming steady-state transport conditions (i.e. solute input $=$ solute loss), the governing equation for conservation of a non reactive solute is;

$$
\frac{\partial}{\partial z}\left[D_{l} \frac{\partial c}{\partial z}\right]-v(z) \frac{\partial c}{\partial z}+c_{\text {plant }} \frac{q_{E T}}{L}=0,
$$

where $c$ is the solute concentration in the pore water, $c_{\text {plant }}$ is the solute concentration in the plant transpiration stream, $L$ is the depth over which root extraction occurs, and other variables are as previously defined. The solute balance is complex, requiring knowledge of depth dependence in $v$ and $D_{l}$ (i.e. the effective depth of mixing by infiltration and drainage fluxes), as well as knowledge of root water extraction, and the degree to which vegetation is able to exclude the solute of interest. These dependences have not been studied in tidal marshes. This level of detailed knowledge is not necessary, however, to apply the model to a subtidal sediment where root extraction is zero and $v$ and $D_{l}$ can more reasonably be assumed to be constant with depth. The steady state solute balance for the subtidal sediment is;

$$
D_{l} \frac{\partial^{2} c}{\partial z^{2}}-v \frac{\partial c}{\partial z}=0 .
$$

Note that since the first term in Eq. (8) accounts for diffusion and the second term for advection, the equation implies that downward diffusion of salt will be balanced by upward advection in a subtidal shoreline soil.

Our approach was to solve Eq. (8) for subtidal sediments and then to modify the solution for application in tidal marshes. Solutions for the vertical distribution of salt were then compared with salinity profiles in marshes and adjacent 


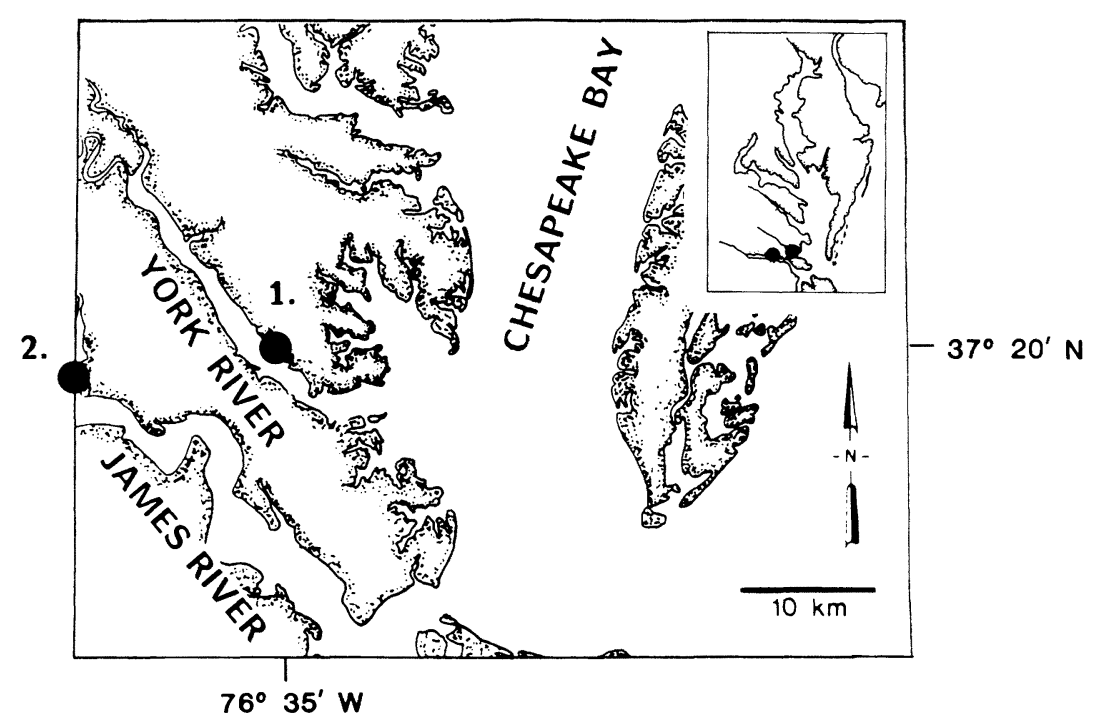

Fig. 2. Location of study sites. 1, Carter Creek marsh $\left(37^{\circ} 20^{\prime} \mathrm{N}, 76^{\circ} 35^{\prime} \mathrm{W}\right) ; 2$, Eagle Bottom marsh $\left(37^{\circ} 18^{\prime} \mathrm{N}, 76^{\circ} 53^{\prime} \mathrm{W}\right)$.

subtidal sediments. Insight gained from that exercise allowed us to assess the relative degree of mixing in the sediment, and its dependence on depth in both shoreline environments.

\section{Study sites}

Two study sites were selected in the lower York and James River estuarine sub-basins of the Western Chesapeake Bay (Fig. 2). At Carter Creek and Eagle Bottom, tidal marsh soils are $80 \mathrm{~cm}$ and $200 \mathrm{~cm}$ in thickness, respectively. Carter Creek marsh is a mesohaline marsh vegetated primarily with Spartina alterniflora. Eagle Bottom marsh is a tidal freshwater marsh vegetated primarily with Peltandra virginica. Both marshes are located at the base of forested hillslopes rising to elevations of 6 to $20 \mathrm{~m}$ above sea level, respectively; each marsh is flooded reguarly by tides with frequencies of inundations exceeding 675 events per year. Both marshes have been the subject of previous ecological investigations (Carter Creek/Wolaver et al. 1983; Harvey et al. 1987; Eagle Bottom/Hoover 1984).

Transects were established in each marsh beginning on the base of hillslope and extending across the marshes at a direction perpendicular to marsh-hillslope interface. Wooden catwalks were constructed to allow access to undisturbed portions of the marsh at measurement stations. At each measurement station piezometers and pore water samplers were installed to depths ranging between $10 \mathrm{~cm}$ and $525 \mathrm{~cm}$ below the marsh surface. 
Soil hydraulic properties, head distribution, and desaturation

At Eagle Bottom data were collected from a total of 7 wells and from 30 piezometers ( $\mathrm{PVC}, 1 \mathrm{~cm}$ inside diameter, $10 \mathrm{~cm}$ screens on piezometers). Piezometers were installed to 4 depths $(25,100,200,425 \mathrm{~cm})$ at 4 locations between the marsh/hillslope border and $40 \mathrm{~m}$ into the marsh. At Carter Creek data were collected from 6 wells and 15 piezometers installed to 4 depths $(25,45,75$, $325 \mathrm{~cm}$ ). These instruments were deployed at 4 locations across $20 \mathrm{~m}$ of marsh. Instrument tops were surveyed with reference to a common datum in each marsh, and water levels within instruments were measured using a graduated, resistance probe.

The piezometers were used to measure the distribution of hydraulic head in each marsh over 6 complete tidal cycles; additional seasonal measurements were made in deeper instruments. Piezometers were also used to measure the saturated hydraulic conductivity of the soil immediately surrounding the screened inlet using a bail test method and the calculation procedure of Luthin \& Kirkham (1949).

The specific yield of each marsh soil $\left(S_{y}\right)$ is defined as the volume of pore water added or released from storage per unit surface area of marsh per unit change in head. Specific yield was measured using gamma ray attenuation at Carter Creek (Harvey et al. 1987) and by volumetric addition of water to a large experimental lysimeter containing an intact core $(30 \mathrm{~cm}$ diam) from Eagle Bottom.

\section{Hydrological fluxes}

Discharge and recharge fluxes were measured or estimated at the station closest to the hillslope in each marsh. Each flux represents an average over six tidal cycles throughout the year.

Groundwater discharge $\left(q_{G W}\right)$ was calculated using Darcy's Law [Eq. (2)] where the hydraulic gradient was taken as the difference of the time averaged hydraulic heads in the underlying aquifer and marsh soil divided by the vertical distance $(X)$ between the piezometer screen in the underlying aquifer and the stratigraphic transition between aquifer and marsh soil.

$$
q_{G W}=K\left(h_{\text {aquifer }}-h_{\text {marsh }}\right) / X .
$$

This scheme of calculation assumes that hydraulic heads do not vary significantly as a function of depth in the marsh soil, which is well supported by data of Fig. 4.

Infiltration fluxes $\left(q_{l}\right)$ were calculated from measurements of the difference in elevation between the marsh surface $\left(z_{s}\right)$ and the mean minimum head at low tide $\left(h_{\min }\right)$. The quantity is multiplied by 2 to account for twice daily tides.

$$
q_{I}=2\left(z_{s}-h_{\min }\right) S_{y} .
$$


Evapotranspiration $\left(q_{E T}\right)$ was estimated from maps of potential evaporation compiled from Weather Bureau data (Kohler et al. 1959). Use of this estimate is justified given Nuttle and Hemond's (1988) finding that calculated potential evaporation was a good predictor of $q_{E T}$ in a New England salt marsh. Pore water drainage $\left(q_{D}\right)$ was calculated by difference using Eq. (1).

\section{Salinity depth distributions}

The concentration of dissolved salts was measured in surface water and at depth in each marsh seasonally for one year. Pore water samples were obtained from piezometers and pore water samplers constructed from PVC pipe ( $5 \mathrm{~cm}$ o.d.), in which the inlet was capped with $70 \mu \mathrm{m}$ porous nylon fritware.

All instruments were completely evacuated prior to sampling. Sample salinities at Carter Creek were measured using a temperature compensated refractometer (Reichert model 10419). At Eagle Bottom the specific conductivity of samples was measured using a salinity-temperature-conductivity meter (YSI model 33). Conductivities were transformed to account for temperature variation to values at $25^{\circ} \mathrm{C}$ using data provided by the manufacturer. One set of samples from Eagle Bottom was brought to the laboratory for determination of specific conductivity and chloride concentrations. Chloride was determined using an ion specific electrode (Orion model 961700). Specific conductivity and chloride concentration were highly correlated at Eagle Bottom $(r=0.985)$.

\section{Results}

\section{Hydraulic conductivity and hydraulic head distribution}

Marsh soils at the study sites consisted of an organic root zone (20-45\% AFDW) overlying mixtures of sand and organic matter (15\% AFDW) to depths up to $2 \mathrm{~m}$. Beneath marsh deposits were Pleistocene or older mixtures of sand and clay with a low organic matter content. Saturated hydraulic conductivities $(K)$ were high in the root zone of both marshes and declined rapidly with depth (Fig. 3). Root zones had hydraulic conductivities equivalent to that of a fine sand; the mineral and humified organic mixtures at the base of the marsh soils possessed hydraulic conductivities similar to silty sands. The hydraulic conductivity of the pre-Holocene aquifer beneath Eagle Bottom marsh was typical of clays and was more than an order of magnitude lower than $K$ values from the aquifer beneath Carter Creek.

Figure 4 shows that the hydraulic head at depth in the marsh soil was at all times similar to the elevation of the phreatic (free water) surface both above and below the soil surface. Drawdown of the phreatic surface is the result of pore water drainage and evapotranspiration; infiltration occurs as the marsh surface is flooded by the rising tide. In Fig. 4 relatively large fluctuations in the average hydraulic head at depth are accompanied with relatively minor differences 


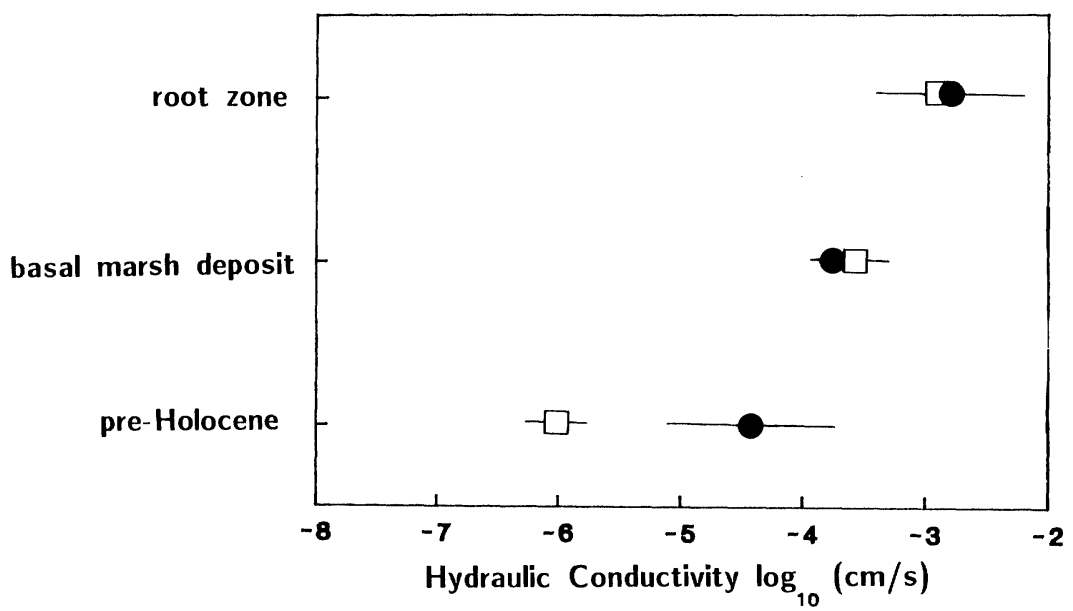

Fig. 3. Hydraulic conductivity vs. stratum in two marshes; Carter Creek (circles) and Eagle Bottom (squares). Error bars are standard errors.

between depths. These data indicate that the pressure responses to soil desaturation and infiltration are rapid and that they are transmitted throughout the entire depth of the marsh soil.

Hydraulic heads were much greater in the underlying aquifer (Fig. 5). The upward hydraulic gradient beneath the marsh is evidence that groundwater is being discharged into the marsh soil from below. Variation in hydraulic head in the underlying aquifer was small over the tidal cycle (J. Harvey, pers. observ.) and some seasonal variation was apparent; hydraulic heads in the aquifer were highest in March and lowest in October. Average upward hydraulic gradients were lower at Carter Creek (0.15 vs. 0.56 at Eagle Bottom).

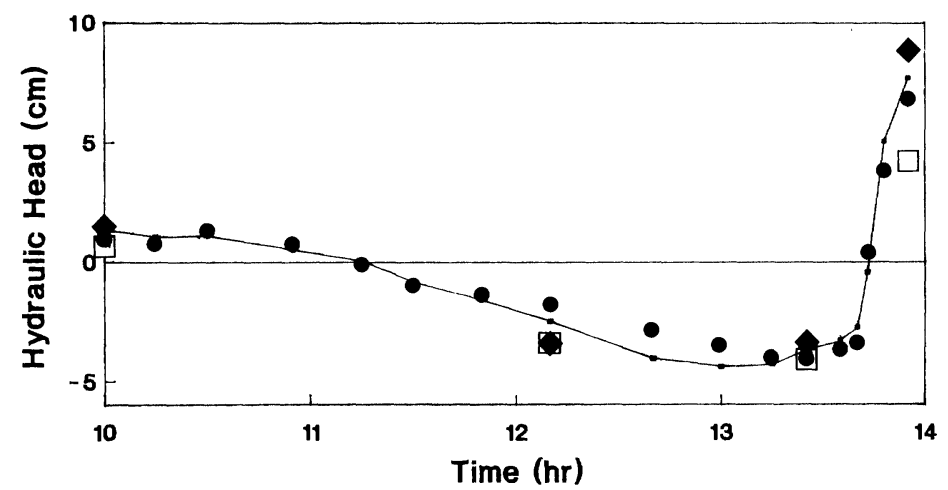

Fig. 4. Hydraulic head vs. time at Eagle Bottom, August 15, 1987. The location of measurements was station 1 (Fig. 4). The zero datum is the average surface elevation of the marsh at station 1. Heads were measured in a well (solid line) and at $25 \mathrm{~cm}$ (circles). $100 \mathrm{~cm}$ (diamonds), and $200 \mathrm{~cm}$ (open squares) below the marsh surface. 


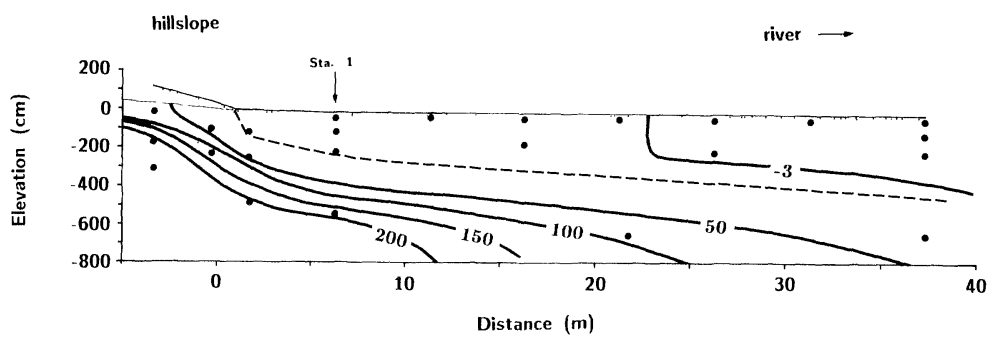

Fig. 5. Distribution of hydraulic head beneath Eagle Bottom marsh; August 15, 1987, low tide. Solid circles are locations of piezometer screens, solid lines are hand contoured lines of equal hydraulic head in units of $\mathrm{cm}$. Zero datum in the elevation of the march surface at station 1 . The dashed line is the location of the transition between the marsh soil and the underlying aquifer.

\section{Groundwater discharge}

Average subsurface discharge of groundwater into marsh soils was calculated from Eq. (2) for 3 stations on the transect at Carter Creek and 4 stations on the transect at Eagle Bottom (Fig. 6). Maximum groundwater discharge occurred closest to the base of the hillslope and discharge declined with distance from the hillslope in both marshes. The change in discharge with distance was best described by a linear decrease at Eagle Bottom; at Carter Creek the number and distribution of data points were insufficient to distinguish a linear decrease from an exponential one. Cumulative discharge (per meter of marsh shoreline) was higher at Carter Creek (10.4 liters $\mathrm{m}^{-1}$ day $^{-1}$ vs. 5.7 liters $\mathrm{m}^{-1}$ day $^{-1}$ at Eagle Bottom).

\section{Pore water balance}

Groundwater discharge rates were combined with estimates of infiltration, evapotranspiration and drainage at each marsh (Table 1). Infiltration fluxes were approximately 12 liters $\mathrm{m}^{-2} \mathrm{~d}^{-1}$ and were the largest fluxes in both marshes;

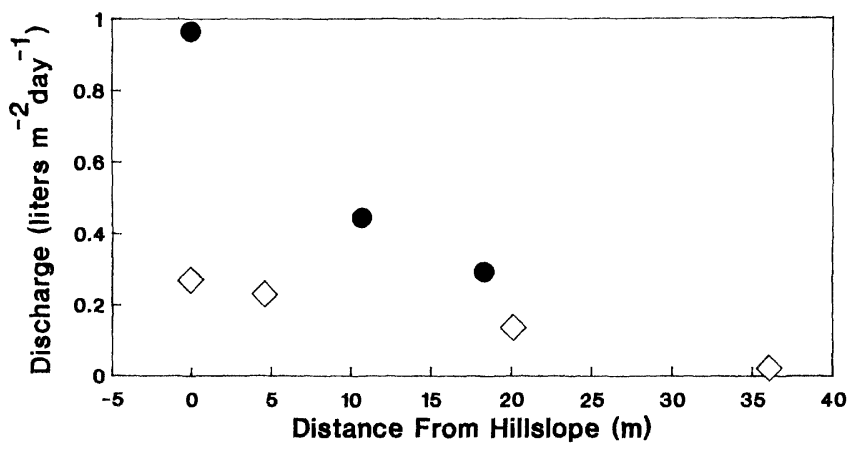

Fig. 6. Groundwater discharge beneath two fringing tidal marshes. Va.: Carter Creek (circles); Eagle Bottom (diamonds). 
Table 1. Subsurface hydrological fluxes in fringing tidal marshes.

\begin{tabular}{|c|c|c|c|c|c|c|c|}
\hline \multirow[t]{2}{*}{ Marsh } & \multirow{2}{*}{$\begin{array}{l}\text { Soil } \\
\text { depth } \\
(\mathrm{cm})\end{array}$} & \multirow[t]{2}{*}{$\begin{array}{l}\text { Porosity } \\
n\end{array}$} & \multicolumn{4}{|c|}{$\begin{array}{l}\text { Hydrological fluxes* } \\
\qquad\left(\text { liters } \mathrm{m}^{-2} \mathrm{day}^{-1} \text { ) }\right.\end{array}$} & \multirow[t]{2}{*}{$\begin{array}{l}\% \text { Groundwater } \\
G W /(I+G W)\end{array}$} \\
\hline & & & $I$ & $G W$ & $E T$ & $D$ & \\
\hline Carter & 75 & 0.83 & 11.0 & 1.0 & 2.8 & 9.2 & $8 \%$ \\
\hline Eagle & 200 & 0.70 & 12.9 & 0.2 & 2.8 & 10.3 & $2 \%$ \\
\hline
\end{tabular}

* $I, G W, E T$ estimated independently, $D$ calculated by difference.

pore water loss was primarily by drainage and secondarily by evapotranspiration at a ratio of approximately 3.5:1. In both marshes groundwater inputs were more than an order of magnitude less than fluxes across the marsh surface (Table 1).

\section{Salt transport model}

A transport model for salt in the marsh soil should consider all hydrological fluxes of Eq. (1) and should also account for dessication and increased dispersion of salt near the marsh surface due to greater velocities associated with infiltration, drainage and evaporation fluxes. Hydrological fluxes due to exchange of pore water with surface water and the atmosphere must decline with depth in the soil but, unfortunately, no measurements of depth dependence in infiltration, drainage and evapotranspiration exist for marshes. For the purpose of this paper we will assume that the depth of the root zone is the effective depth of dispersive mixing with surface water. This choice seems reasonable given that this depth is the depth over which root water uptake occurs, and the depth in which soil hydraulic conductivity remains high (Fig. 3).

Solute transport in the root zone is modeled as follows; $c_{s}$ is the concentration of infiltrating water (assumed in these regularly flooded marshes to equal the average concentration of flooding surface water) and $c_{0}$ is the average concentration of salt in the root zone of depth $L$. The mass balance of salt in the zone due to exchange of pore water and surface water is:

$$
n L \frac{\mathrm{d} c_{0}}{\mathrm{~d} t}=q_{i} c_{s}-q_{d} c_{0} .
$$

If $c_{0}$ and $c_{s}$ do not change with time then the left side of Eq. (11) equals zero and the equation can be rearranged to find $c_{0}$ as a function of $c_{s}$ and the infiltration and drainage fluxes.

$$
c_{0}=\frac{q_{i}}{q_{d}} c_{s} .
$$

The salinity of the root zone is higher than that of surface water by a factor equal to the ratio of infiltration to drainage fluxes. The higher salinity of the root 
zone results from dessication of pore water. The assumption of well mixed conditions in the root zone implies that dispersion due to $I, D$ and $E T$ is much larger than that due to $G W$. This assumption is reasonable given the dependence of the dispersion coefficient on fluxes [Eq. (6)] and the relative magnitude of those fluxes in our marshes (Table 1).

Beneath the root zone the salt flux is assumed to be zero, i.e. held in balance between upward advective transport by groundwater and downward diffusion [Eq. (8)]. This steady state analysis, like the one for the root zone, ignores seasonal changes in salinities. The solution for concentration beneath the root zone comes from an analytical solution for Eq. (8):

$$
c(z)=c_{0} \exp \left(-v_{G W} z^{\prime} \mid D_{l}\right),
$$

where $z^{\prime}$ is the depth beneath the bottom of the root zone $\left(z^{\prime}=z-L\right)$. Combining the compartment model with Eq. (13) leads to a complete solution for salt concentration versus depth in the marsh subject to the following boundary conditions:

$$
\begin{array}{ll}
z=0 & c=c_{s} \\
0<z \leqslant L & c=c_{0}=\frac{q_{I}}{q_{\mathrm{D}}} c_{s} \\
L<z<\infty & c=c_{0} \exp \left(-v_{G W} z^{\prime} \mid D_{l}\right) \\
z=\infty & c=0 .
\end{array}
$$

The solution for the subtidal beach is:

$$
\begin{array}{ll}
z \leqslant 0 & c=c_{s} \\
0<z \leqslant \infty & c=c_{s} \exp \left(-v_{G W} z / D_{l}\right) \\
z=\infty & c=0 .
\end{array}
$$

This portion of the solution has commonly been used for salt transport in soils and has previously suggested for modeling salt transport in marshes (Redfield 1959).

The complete salt transport model for the marsh requires an average surface water salinity $\left(c_{s}\right)$, an upward groundwater velocity $\left(v_{G W}\right)$, estimates of infiltration and drainage fluxes $(I$ and $D)$, and a dispersion coefficient $\left(D_{l}\right)$, which depends on $v_{G W}$ and a dispersivity coefficient $(\alpha)$. Dispersivities range over orders of magnitude in nature and the normal procedure is to estimate them by fitting models to data. This approach is acceptable for our comparison of the shape of measured and modeled depth distributions of salinity (e.g. exponential vs. linear or sigmoid) because basic features of profile shape are not affected by choice of a dispersivity coefficient.

Figure 7 compares the vertical salinity distribution in the Carter Creek marsh 


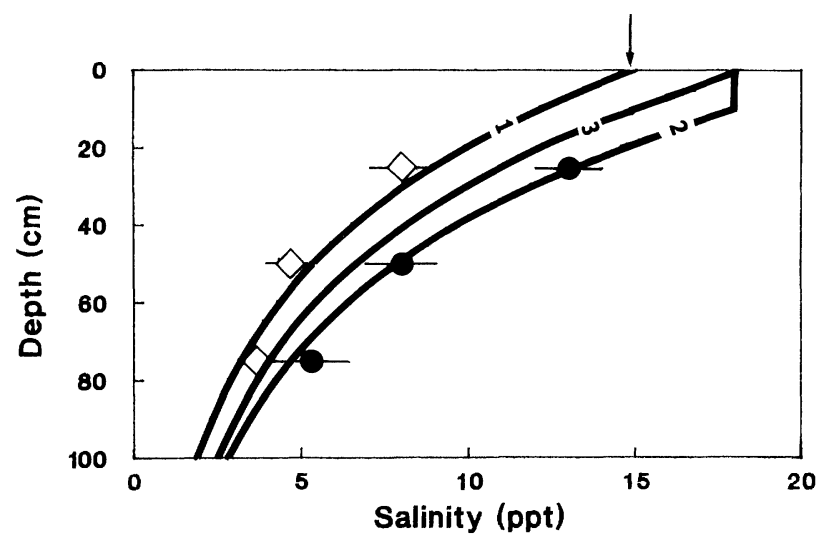

Fig. 7. Depth distribution of pore water salinities at Carter Creek marsh (circles) and a nearby subtidal mudflat (diamonds). Error bars are standard errors. The modeled salinity distributions are plotted as thick black lines; (1) subtidal model, (2) marsh model and (3) marsh model with dessication only. Parameter values for the models were: $c_{s}=15 \mathrm{ppt}, L=10 \mathrm{~cm}, v=0.12 \mathrm{~cm} \mathrm{~d}^{-1}$, $D_{l}=5.8 \mathrm{~cm}^{2} \mathrm{~d}^{-1}$. The surface water salinity $\left(c_{s}\right)$ is indicated by an arrow.

and a nearby, subtidal mudflat. The agreement between data and the solution for a subtidal flat is good. The addition of a well mixed, root zone in the marsh model provides an adequate explanation for deviations between marsh and subtidal beach. The comparison of measured and modeled shapes of salinity distributions suggest that dessication and increased dispersion in the root zone of the marsh are responsible for the higher steady state salinities at depth in the marsh soil. A third model was formulated to simulate dessication without dispersion in the marsh (subtidal solution using $c_{s}=c_{0}$ ). A significant proportion of the higher salinities in the marsh (Fig. 7) could not be explained by dessication alone, suggesting further that increased mixing in marsh soils is important.

In Fig. 8, average specific conductances from station 1 at Eagle Bottom are plotted along with model output. Specific conductance varies seasonally in the root zone following changes in surface water conductances in the Chickahominy River; the mean annual conductance of flooding surface water is shown on the abscissa in Fig. 8. The marsh model cannot capture the seasonal dynamics of salt content in the root zone (dashed lines) but does approximate the shape of the average vertical distribution better than the subtidal model. The greater apparent turnover of pore water in the root zone (suggested by large seasonal changes in salt content) is also consistent with the concept of higher pore water velocities and more intense mixing due to desaturation and infiltration fluxes. Beneath the root zone the shape of the distribution of conductance is explained well by the marsh model. 


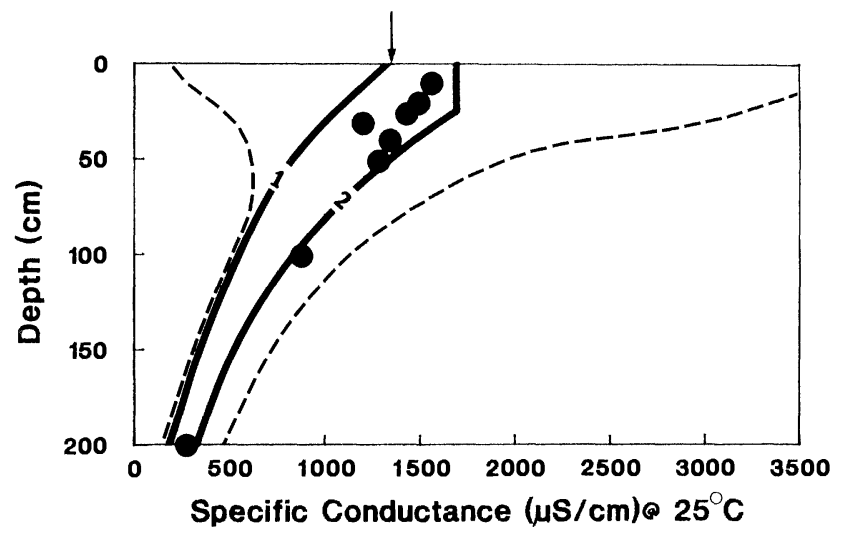

Fig. 8. Depth distribution of pore water specific conductance at Eagle Bottom marsh. The average annual conductances are plotted as circles and model output as thick black lines; (1) subtidal model, (2) marsh model. The annual range in conductance values are plotted as dashed lines. Parameter values for the models were: $c_{s}=1350 \mu \mathrm{S} / \mathrm{cm}, L=25 \mathrm{~cm}, v=0.03 \mathrm{~cm} \mathrm{~d}^{-1}, D_{l}=3.2 \mathrm{~cm}^{2} \mathrm{~d}^{-1}$. Average conductance of surface water $\left(c_{s}\right)$ is indicated by an arrow.

\section{Discussion}

\section{Controls on discharge magnitudes and pathways}

The geometry and hydraulic conductivity of unconfined aquifers are factors known to control pathways and magnitudes of upland groundwater discharge to surface water bodies (McBride \& Pfannkuch 1977). Our results agree with previous field observations in estuaries; discharge was greatest at the shoreline and decreased with distance offshore (Bokuniwiez 1980; Valiela et al. 1980; Capone \& Bautista 1985; Simmons et al. 1988). Subsurface flow in a water table aquifer is dependent upon the slope in the water table which is large near the topographic break in slope at the upland-estuarine interface. Discharge rates that decline with distance from shore support the conjecture that the dominant source of groundwater at estuarine shorelines is from the local water table aquifer rather than a deeper, regional aquifer. Predominant discharge from a local aquifer is also consistent with the classification of deeper aquifers in our study region as semi-confined (Cederstrom 1943).

Calculated discharge of groundwater at Eagle Bottom was about half that at Carter Creek. The low hydraulic conductivity of the underlying aquifer at Eagle Bottom, and the greater thickness of the basal marsh deposit appear to have been important in restricting discharge there. The hydraulic conductivity of the underlying aquifer at Carter Creek was 100 times that of Eagle Bottom; the effect of the higher $K$ on discharge was largely, but not completely, offset by the lower hydraulic gradient at Carter Creek. Differences in discharge at these sites illustrate the importance of variation in upland elevation and slope in controlling discharge at estuarine shorelines. 
Table 2. Upland groundwater discharge at estuarine shorelines.

\begin{tabular}{|c|c|c|}
\hline \multirow[t]{2}{*}{ Location } & \multicolumn{2}{|l|}{ Discharge } \\
\hline & $\begin{array}{l}\text { Total } \\
\left(\text { liters } \mathrm{m}^{-1} \mathrm{~d}^{-1}\right)\end{array}$ & $\begin{array}{l}\text { Maximum } \\
\text { (liters } \mathrm{m}^{-2} \mathrm{~d}^{-1}\end{array}$ \\
\hline \multicolumn{3}{|l|}{ Subtidal } \\
\hline Islip, NY (1) [1] & 2079 & 80 \\
\hline Islip, NY (2) [1] & 1078 & 36 \\
\hline Heckscher ST. Park, NY [1] & 8404 & 48 \\
\hline Bayport, NY [1] & 3868 & 105 \\
\hline Chincoteague, VA [2] & - & 26 \\
\hline Bogue Sound, NO [3] & - & 28 \\
\hline Duke Marine Lab, NC [3] & - & $9-64$ \\
\hline \multicolumn{3}{|l|}{ Tidal Marsh } \\
\hline $\begin{array}{l}\text { Sippewissett, MA [4] } \\
\text { (marsh, springs, creeks) }\end{array}$ & 4397 & 11 \\
\hline $\begin{array}{l}\text { Sippewissett, MA [5] } \\
\text { (marsh only) }\end{array}$ & - & 6 \\
\hline Carter Creek, VA [6] & 10 & 1 \\
\hline Eagle Bottom, VA [6] & 6 & 0.2 \\
\hline
\end{tabular}

References:

[1] Bokuniewicz (1980)

[2] Simmons et al. (1988)

[3] Lee (1977)

[4] Valiela et al. $(1978,1980)$, using marsh dimensions $1530 \mathrm{~m} \times 400 \mathrm{~m}$.

[5] Hemond \& Fifield (1982); using gradient and $K$ from run 1.

[6] This study

Highly conductive aquifers of Mid-Atlantic barrier islands and glacial deposits of Long Island, and Cape Cod are composed of low organic, coastal sands. Groundwater discharge from these aquifers is often higher than drainage and evapotranspiration fluxes from tidal marshes of those latitudes (Nuttle \& Hemond 1988; this study). A potential exists in those areas for obstruction or rerouting of groundwater by marsh deposits. Calculations using published data (Valiela et al. 1978; Valiela et al. 1980; Hemond \& Fifield 1982) from Great Sippewissett Marsh, MA on Cape Cod indicate that much of the groundwater must be discharged through preferential flow paths in the clean glacial sand without contacting the marsh soil (Table 1). The marsh soil is thin in many portions of Sippewissett and sand is exposed at the bottom of many creeks and on island-like mounds of sand that stand above sea level (Treggor 1983). Partial bypassing of the marsh soil by discharging groundwater agrees with the identification of groundwater springs at the base of these mounds and in creek bottoms Valiela et al. (1980).

Hydrologic data from numerous estuarine shorelines of the eastern United States reveal a wide range in groundwater discharges (Table 2). It should be noted that many of the discharge estimates of Table 2 are direct estimates using seepage measurements (Lee 1977; Bokunieweiz 1980; Simmons et al. 1988), 
others estimates are based on creek discharge and dilution measurements (Valiela et al. 1978, 1980) and some estimates are calculations that rely on measurements of hydraulic gradients and hydraulic conductivities (this study). Direct water balance measurements are always desirable in water budgets but can not always be obtained, as in the case where groundwater discharge is by flow into marsh soils from beneath. Gradient/conductance calculations provide a theoretically valid estimate of upland aquifer discharge into marsh soils, but standard errors of the estimates are large. We believe that the use of these estimates is justified given that more direct methods of measuring this particular flux using seepage meters are not possible. Use of gradient/conductance calculations is also justified given that the results can be checked for reasonableness through use of salt distribution data and transport models.

Together, the data of Table 2 indicate that where clay or organic muds are present in substantial proportions in coastal aquifer sediments, or in basal marsh deposits, groundwater discharge is small. Where these materials are absent or present only in thin layers, discharge can be up to 2 orders of magnitude higher if adequate local recharge occurs and aquifer geometry permits. Consideration of these data and data from our marshes lead us to draw the following general conclusions concerning effects of marshes on flow paths and magnitudes of groundwater discharging to estuaries:

- Much of the groundwater that is discharged directly to estuaries is intercepted by marshes near the hillslope interface, the groundwater is then a component of the marsh pore water subject to dessication and mixing with pore water derived from surface infiltration.

- Where clay or mud is present in the underlying aquifer or in a thick basal deposit in the marsh, groundwater discharge will normally be a much smaller component of total inflow to tidal marsh soils than infiltration.

- Where highly conductive, sand aquifers are topped with thin tidal marsh deposits, as on Cape Cod, discharge of groundwater may be preferentially channeled through sandy creek bottoms or possibly beneath the marsh to offshore areas.

- Very shallow groundwater flow from near surface, hillslope soils into the marsh through the high conductivity root zone may be an important transport pathway. Direct discharge from the base of the hillslope onto the marsh surface at seeps may also occur.

\section{Transport in tidal marshes vs. subtidal sediments}

By preliminary calculation, the residence time of water in a tidal marsh soil will be longer in than in a subtidal sediment; the difference in residence time will be approximately equal to the elevation difference between the deposits divided by the groundwater velocity. Soil contact times for our area are on the order of 50 to $100 \%$ longer for groundwater entering a marsh deposit than a subtidal beach.

Pore water drainage, evapotranspiration, and infiltration are important water fluxes in tidal marshes that do not occur in subtidal estuarine sediments. What 
is the effect of having these marsh fluxes superimposed on the relatively smaller groundwater discharge flux? A steady state model for salt transport in estuarine sediments predicted a slow, upward transport of salt in the sediments balanced by downward diffusion. For marshes, a root zone component was added to the model to represent a well mixed layer wherein pore water is exchanged with surface water on each tidal cycle. This simple modification improved the fit to data when compared to the subtidal model. Dessication alone cannot explain differences in salt distributions in the marsh soils. A marsh model that incorporated dessication but not increased dispersion yielded profiles of salt concentration that were similar in shape (i.e. exponential) to subtidal profiles and only somewhat higher in salinity at any depth. Measured and modeled profiles of dissolved salt concentrations in tidal marsh soils were different in shape, tending more toward linear or sigmoid profiles with considerably higher salinities at any depth. The conclusion reached is that greater dispersive mixing occurs in tidal marsh soils than in subtidal sediments. Some mixing occurs in both environments due to bioturbation and bubble ebullition. The greater mixing in marsh soils most probably results from the large fluxes of pore water that occur in the root zone by pore water loss and replacement across the marsh surface. Solutes in marsh soils are mixed vigorously to a depth of 10 to $25 \mathrm{~cm}$; pore water exchange across the sediment surface does not occur with the same intensity in subtidal shoreline sediments.

The salt transport model proved useful in distinguishing differences between transport conditions in tidal marsh soils and subtidal beaches, but has limited utility at smaller spatial scales (i.e. top $20 \mathrm{~cm}$ ) or in marshes without groundwater input. The assumption of well mixed conditions in the root zone is first order, to be used as a starting point or end member (opposite a purely diffusive transport assumption) for further analysis of controls on transport at depth. More data on subsurface fluxes of pore water and solute will be needed for this effort.

\section{Conclusions}

Groundwater discharged from the upland aquifer is retained longer in tidal marsh soils than in subtidal shoreline sediments. In addition, groundwater and entrained solute are mixed more thoroughly with surface water and pore water in marsh soils than subtidal sediments, prior to final export to the estuary. These findings have important implications for transport of reactive solutes through tidal marsh soils. Longer soil contact times of groundwater in marshes and root water uptake may be important for nutrient immobilization. For example, plant uptake was a major pathway for the removal of nitrate in groundwater entering Great Sippewissett Marsh, MA (Valiela \& Teal 1979). Drawdowns in the water table and frequent input of surface water by infiltration in marsh soils may also be important. Water table drawdowns lead to oxidizing conditions in the root zone that are important to nitrogen immobilization by bacteria (Bowden 1986), 
phosphorous sortion onto iron oxyhydroxides (Chambers \& Odum, in review), and increased denitrification (Brosemer et al. 1987). Enhanced mixing in marsh soils might be of considerable importance in modulating biogeochemical reactions. It may, for example, lead to a partial release of denitrifiers from carbon limitation where groundwater nitrate inputs are high. Estuarine surface waters and marsh pore waters are relatively rich in dissolved organic carbon but discharging groundwater is often depleted in dissolved carbon. Experiments by Slater \& Capone (1987) showed that denitrification was carbon limited in a subtidal estuarine sediment in which high nitrate groundwater was advecting upward. These potentially higher rates of denitrification in marsh soils could be of large importance to estuarine nitrogen budgets where input of nitrate with groundwater is high.

The function of tidal marshes in estuaries has long been a topic of concern in ecosystem ecology. The traditional emphasis was on budgets for the transport of materials between uplands, marshes and estuaries (reviewed by Nixon 1980). More recent work has focused on processes, such as the importance of subsurface fluxes in the exchange of energy and materials between marsh and estuary (e.g. Jordan \& Correll 1985). Renewed attention on the interconnectedness between upland aquifers and fringing tidal marshes is now providing new hypotheses concerning the role of marshes in modifying subsurface fluxes between upland and estuary. This most recent avenue of research recognizes the enormous impact that shorefront urbanization has had on groundwater quality, and the potential that direct groundwater discharge to estuaries has to alter nutrient cycling, trophic structure and secondary production in estuaries for years to come.

\section{Acknowledgements}

This research was supported by funding from NOAA through the administration of the Virginia Sea Grant Consortium (grant 1988 VGMSC-UVA-O to W.E. Odum, J.W. Harvey and R.M. Chambers). We thank R.M. Chambers, L.P. Rozas, and B.H. Hussey for assistance in fieldwork and W.K. Nuttle plus three anonymous reviewers for helpful criticism of the manuscript.

\section{References}

Back W (1966) Hydrochemical facies and groundwater flow patterns in northern part of Atlantic Coastal Plain. Geological Survey Professional Paper 498-A, United States Government Printing Office, Washington D.C., $42 \mathrm{p}$

Bokuniewicz H (1980) Groundwater seepage into Great South Bay, New York. Estuarine, Coastal and Shelf Science 10: 437-444

Bowden WB (1986) Nitrification, nitrate reduction and nitrogen immobilization in a tidal freshwater marsh sediment. Ecology 67: 88-99

Brosemer KM, Nuttle WK, Winstead EL, Levine JS \& Cofer WR (1987) Denitrifier activity and biogenic emission of $\mathrm{N}_{2} \mathrm{O}$ from wetlands: the effect of tidal action. Eos Trans. AGU 68: 1224 
Capone DG \& Bautista MF (1985) A groundwater source of nitrate in nearshore marine sediments. Nature 313: 214-216

Cederstrom DJ (1943) Geology and groundwater resources of the Coastal Plain of Virginia. Virginia Geological Survey Bulletin 63, 384 pp

Chambers RM \& Odum WE (1990) Porewater Oxidation, dissolved phosphate and the iron curtain: Iron-phosphorus relations in tidal freshwater marshes. Biogeochemistry 10:37-52

Cooper HH, Kohout FA, Henry HR and Glover RE (1964) Sea water in coastal aquifers. U.S. Geological Survey Water Supply Paper 1613-c, 84pp

Dacey JWH \& Howes BL (1984) Water uptake by roots controls water table movement and sediment oxidation in short Spartina marsh. Science 224: 487-489

Freeze RA \& Cherry JA (1979) Groundwater. Prentice-Hall, Englewood Cliffs, NJ. 604 p

Glover RE (1959) The pattern of freshwater flow in a coastal aquifer. J. Geophys. Res. 64: 457-459

Harvey JW, Germann PF \& Odum WE (1987) Geomorphological control of subsurface hydrology in the creekbank zone of tidal marshes. Estuarine, Coastal and Shelf Science 25: 677-691

Hayden BP \& Dolan R (1979) Barrier islands, lagoons and marshes. J. Sedimentary Petrology 49: 1061-1072

Hemond HF \& Fifield JL (1982) Subsurface flow in salt marsh peat: a model and field study. Limnology and Oceanography 27: 126-136

Henry HR (1960) Saltwater intrusion into coastal aquifers. Intern. Assoc. Sci. Hydrol. Publ. 52. pp 478-487

Hoover JK (1984) Spatial and temporal niche relationships in a tidal freshwater macrophyte community. Masters thesis. Department of Environmental Sciences. University of Virginia, $85 \mathrm{p}$

Johannes RE \& Hearn CJ (1985) The effect of submarine groundwater discharge on nutrient and salinity regimes in a coastal lagoon off Perth, Western Australia. Estuarine, Coastal and Shelf Science 21: 789-800

Jordan TE \& Correll DL (1985) Nutrient chemistry and hydrology of interstitial water in brackish tidal marshes of Chesapeake Bay. Estuarine, Coastal and Shelf Science 21: 45-55

Kohler MA, Nordenson TJ \& Baker DR (1959) Evaporation maps for The United States. Tech. Pap. 37, US Weather Bur. Dep. of Commerce, Washington, D.C. 1959

Kraft JC, Allen EA, Belknap DF, John CJ \& Maurmeyer EM (1979) Processes and morphologic evolution of an estuarine and coastal barrier system. In: Leatherman SP (Ed) Barrier Islands (pp 149-184). Academic Press, New York. 325 p

Lee DR (1977) A device for measuring seepage fluxes in lakes and estuaries. Limnology and Oceanography 22: 140-147

Luthin JN \& Kirkham D (1949) A piezometer method for measuring permeability of soil in situ below a water table. Soil Science 68: 349-358.

McBride MS \& Pfannkuch HO (1975) The distribution of seepage within lakebeds. Journal of Research of the United States Geological Survey 3: 505-512

Nixon SW (1980) Between coastal marshes and coastal waters - a review of twenty years of speculation and research on the role of salt marshes in estuarine productivity and water chemistry. In: Hamilton P \& McDonald KB (Eds) Estuarine and Wetland Processes (pp 437-525). Plenum Press, New York

Nuttle WK (1988) The extent of lateral water movement in the sediments of a New England salt marsh. Water Resources Research 24: 2077-2085

Nuttle WK \& Hemond HF (1988) Salt marsh hydrology; implications for biogeochemical fluxes to the atmosphere and estuaries. Global Biogeochemical Cycles 2: 91-114

Redfield AC (1959) Circulation of heat, salt and water in salt marsh soil. Proceedings of the Salt Marsh Conference, University of Georgia, Athens. March (1958)

Simmons GM, von Schmidt-Pauli K, Waller J \& Lemourex E (1988) The role of submarine groundwater discharge in transporting nutrient flux to coastal marine environments. Virginia Waters: Current Developments. Water Resources Research Center. V.P.I., Blacksburg, Va. $52 \mathrm{p}$

Slater JM \& Capone DG (1987) Denitrification in aquifer soil and nearshore marine sediments influenced by groundwater nitrate. Applied and Environmental Microbiology 53: 1292-1297 
Treggor JP (1983) The development and geomorphology of the Great Sippewissett Marsh. Masters Thesis. Central Connecticut State University

Valiela I \& Teal JM (1979) The nitrogen budget of a salt marsh ecosystem. Nature 280: 652-656

Valiela I, Teal JM, Volkmann SB, Cogswell CM \& Harrington RA (1980) On the measurement of tidal exchanges and groundwater flow in salt marshes. Limnology and Oceanography 25: 187-182

Valiela I, Teal JM, Volkmann S, Shafer D \& Carpenter EJ (1978) Nutrient and particulate fluxes in a salt marsh ecosystem: Tidal exchanges and inputs by precipitation and groundwater. Limnology and Oceanography 23: 798-812

Winner MD (1975) Groundwater resources of the Cape Hatteras National Seashore. North Carolina. U.S. Geol. Surv. Hydrol. Investig. Atlas HA-540. Washington, D.C.

Wolaver TG, Zieman JC, Wetzel R \& Webb KL (1983) Tidal exchanges of nitrogen and phosphorus between a mesohaline vegetated marsh and the surrounding estuary in the lower Chesapeake Bay. Estuarine Coastal Shelf Science 16: 321-332 
http://www.jstor.org

\title{
LINKED CITATIONS
}

- Page 1 of 2 -

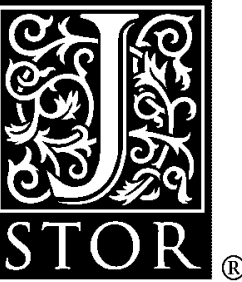

You have printed the following article:

The Influence of Tidal Marshes on Upland Groundwater Discharge to Estuaries

Judson W. Harvey; William E. Odum

Biogeochemistry, Vol. 10, No. 3, Groundwater Inputs to Coastal Waters. (Aug., 1990), pp.

217-236.

Stable URL:

http://links.jstor.org/sici?sici=0168-2563\%28199008\%2910\%3A3\%3C217\%3ATIOTMO\%3E2.0.CO\%3B2-4

This article references the following linked citations. If you are trying to access articles from an off-campus location, you may be required to first logon via your library web site to access JSTOR. Please visit your library's website or contact a librarian to learn about options for remote access to JSTOR.

\section{References}

\author{
Nitrification, Nitrate Reduction, and Nitrogen Immobilization in a Tidal Freshwater Marsh \\ Sediment \\ William B. Bowden \\ Ecology, Vol. 67, No. 1. (Feb., 1986), pp. 88-99. \\ Stable URL: \\ http://links.jstor.org/sici?sici=0012-9658\%28198602\%2967\%3A1\%3C88\%3ANNRANI\%3E2.0.CO\%3B2-4
}

Porewater Oxidation, Dissolved Phosphate and the Iron Curtain: Iron-Phosphorus Relations in Tidal Freshwater Marshes

Randolph M. Chambers; William E. Odum

Biogeochemistry, Vol. 10, No. 1. (May, 1990), pp. 37-52.

Stable URL:

http://links.jstor.org/sici?sici=0168-2563\%28199005\%2910\%3A1\%3C37\%3APODPAT\%3E2.0.CO\%3B2-T

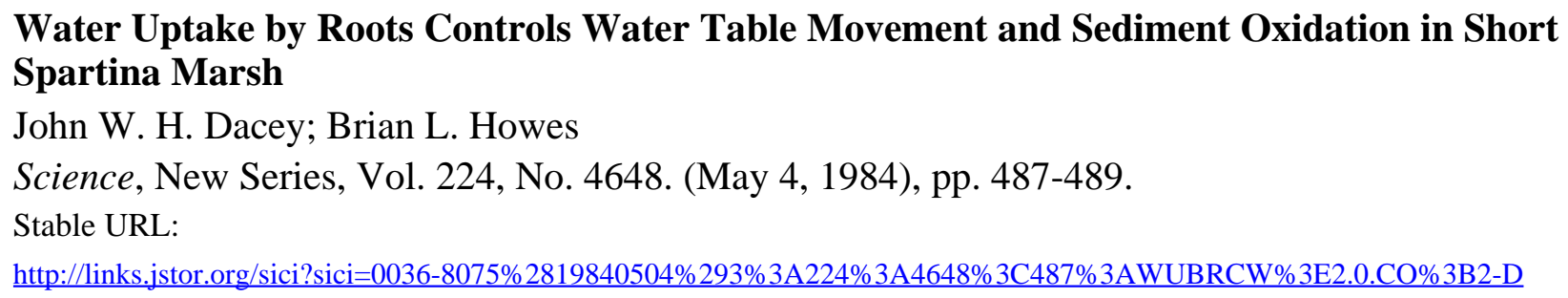


http://www.jstor.org

\title{
LINKED CITATIONS \\ - Page 2 of 2 -
}

Subsurface Flow in Salt Marsh Peat: A Model and Field Study

Harold F. Hemond; Jayne L. Fifield

Limnology and Oceanography, Vol. 27, No. 1. (Jan., 1982), pp. 126-136.

Stable URL:

http://links.jstor.org/sici?sici=0024-3590\%28198201\%2927\%3A1\%3C126\%3ASFISMP\%3E2.0.CO\%3B2-0

\author{
A Device for Measuring Seepage Flux in Lakes and Estuaries \\ David Robert Lee \\ Limnology and Oceanography, Vol. 22, No. 1. (Jan., 1977), pp. 140-147. \\ Stable URL: \\ http://links.jstor.org/sici?sici=0024-3590\%28197701\%2922\%3A1\%3C140\%3AADFMSF\%3E2.0.CO\%3B2-N
}

On the Measurement of Tidal Exchanges and Groundwater Flow in Salt Marshes

Ivan Valiela; J. M. Teal; S. B. Volkmann; C. M. Cogswell; R. A. Harrington

Limnology and Oceanography, Vol. 25, No. 1. (Jan., 1980), pp. 187-192.

Stable URL:

http://links.jstor.org/sici?sici=0024-3590\%28198001\%2925\%3A1\%3C187\%3AOTMOTE\%3E2.0.CO\%3B2-M

Nutrient and Particulate Fluxes in a Salt Marsh Ecosystem: Tidal Exchanges and Inputs by Precipitation and Groundwater

Ivan Valiela; John M. Teal; Suzanne Volkmann; Deborah Shafer; Edward J. Carpenter

Limnology and Oceanography, Vol. 23, No. 4. (Jul., 1978), pp. 798-812.

Stable URL:

http://links.jstor.org/sici?sici=0024-3590\%28197807\%2923\%3A4\%3C798\%3ANAPFIA\%3E2.0.CO\%3B2-1 